\title{
Discurso do Sr. Ministro Pereira Lira na sessão solene realizada pelo Tribunal de Contas em Homenagem a Portugal
}

\begin{abstract}
DISCURSO COM QUE FOI RECEBIDO PELO MINISTRO J. PEREIRA LIRA, PRESIDENTE DO TRIBUNAL DE CONTAS. NO PLENARIO, A DELEGAÇAO DO TRIBUNAL DE CONTAS DE PORT'UIGAL AC "3॰ CONGRESSO INTERNACIONAL DAS INSTITUIÇOES SUPERIORES DE CONTROLLE DAS FINANÇAS PÚBLICAS" EM 12 DE MAIO DE 1959
\end{abstract}

Cabe-me encerrar esta sessão extraordinária, de tão alta expressão cívica e relevante significado de cordialidade internacional, assinalados nas orações que aqui acabam de ser pronunciadas.

Quero renovar os agradecimentos do Tribunal de Contas do Brasil ao Tribunal de Contas de Portugal, pelo gesto carinhosamente vivido, de atender com real solicitude ac nosso convite para participar do $3^{\circ}$ Congresso, ora encerrado com tanto esplendor.

Para o brilho dêsse Conclave concorreu grandemente a Delegação que ora nos visita, integrada pelo Juiz Conselheiro Armando CÂndido DE OLIveira e pelo Dr. João Bartolomeu Jr., sob a Chefia do Ministro Artur Aguedo De Oliveira, um dos Presidentes do Congresso e de uma das mais importantes e delicadas de suas Comissões de Trabalho.

A contribuição dessa ilustre Delegação foi das mais fecundas, das mais ricas de conteúdo, e de excelente apresentação material, versando todo o temário e transbordando para questões outras relacionadas com as Instituições de Contrôle.

Honras, pois, sajam prestadas à Pátria Irmã pelos expoentes que, nesta hora, enviou ao Rio de janeiro, onde já realiza uma inexcedivel obra de cordialidade luso-brasileira o Senhor Embaixador MANUEL FARRAJOTA Rocheta, sempre auxiliado por tão excelsa dama, a Senhora Rocheta, o qual nos deu a honra, especialmente mencionada, de transpor os sóbrios cancelos desta Côrte, para se assentar entre nós.

Temos de consignar, de maneira a mais expressiva, a rica lembrança com que é presenteado, no dia de hoje, o Tribunal de Contas do Brasil.

Esta obra d'arte ficará conosco, como um trecho comum da vida das duas nações que, à face dos séculos, são um só povo orgulhoso da epopéia do passado e das realizaçóes do presente. 
Senhor Ministro Artur Aguedo de Oliveira :

Sinto entre nós, nesta sala, dois ausentes que, por serem vossos, são nossos também: dcis beneditinos da pesquisa do passado comum.

Suas sombras amigas pairam sôbre as nossas cabeças, reforçando-nos a intuição de passado idêntico e de um porvir solidário, de que a raça autêntica e a formosa língua de CAMõEs e de VIEIRA são o maior penhor. Quers recordar os historiadores das nossas Instituições: AlEXANDRE Herculano e Henrique da Gama Barros.

Êle vão rele: conosco as letras do livro que trouxestes, e vão reler, na companhia do Pai espiritual desta Casa - Rui BArbosa.

$E^{\prime}$ esta solenidade mais um elo acrescentado às correntes que soldam as duas Pátrias para a Eternidade...

Está, assim encerrada a sessão extraordinária, realizada em honra de Portugal. 